\title{
17. 高周波無電極放電プラズマにおける㷔光体発光の輝度特性
}

- $\mathrm{Hg}$ 蒸気圧の效果

$$
\begin{aligned}
& \text { 柏㟝 英德 大津 康徳 } \\
& \text { （佐 賀大学） }
\end{aligned}
$$

\section{1.はじめに}

次世代の光源は，環境への配虑，長寿命化，高輝度化等 が大きな課題になると思われる。筆者等は, $\mathrm{Ne}, \mathrm{Ar}$ の各 ガスに Hg ガスを混合して，無電極放電ブラズによる発 光特性を調べ, 長寿命化, 高輝度化に関する基礎的研究 を進めている。昨年の本学会でその一部を報告した ${ }^{(1)}$ 。今年 度は $\mathrm{Hg}$ 蒸気圧, $\mathrm{Ne}, \mathrm{Ar}$ との混合状態等に関連する蛍光 体発光の輝度を調へたたのでその結果を報告する。

\section{2. 実験方法}

図 1 に実験装置を示す。ガスは $\mathrm{Ne}, \mathrm{Ar}, \mathrm{Hg}$ を $\mathrm{Ne}-\mathrm{Hg}$ ， Ar-Hg の混合ガスにしてガス供給部より容器内に入れた。 ガスの圧力は $0.01 \sim 0.1$ Torr まで変化させた。このとき $\mathrm{Ne}-\mathrm{Hg}$, Ar-Hg の各混合ガスの Ar と $\mathrm{Hg}, \mathrm{Ne}$ と $\mathrm{Hg}$ の混合 比を変えるために, Hg の蒸気圧が $2 \times 10^{-3}$ Torr と $2 \times 10^{-4}$ Torr の条件で実験を行った。コイルには高周波電圧 $(13.56$ $\mathrm{MHz}$ )を印加し, 放電電力は, $10 \sim 200 \mathrm{~W}$ まで変化させ, 容量結合型放電(CCP)から誘導結合型放電(ICP)へ放電モ 一ドを変化させた。電子密度は光源部内, $Z=-1 \mathrm{~cm}$ と蛍光 体近傍の $Z=10 \mathrm{~cm}$ の位置に円筒プローブを設置して測定し た。 $\mathrm{Z}=0 \mathrm{~cm}$ は容器の端部とした。またアルミ製筒型容器 の側面にパイレックスガラスに蛍光体を塗布したものを取り 付け，蛍光体の発光輝度と発光色を，色彩輝度計（トプコ ン製）により测定した。使用した営光体は青色発光を促す NP1047 と赤色発光を促すNP320を 2:1で混合したものを 使用した。

\section{3. 実験結果}

困 2，困 3 にそれぞれ Ne-Hg，Ar-Hgにおけるガス圧 0.1 Torr, Hg 蒸気圧 $2 \times 10^{-3}$ Torr および $2 \times 10^{-4}$ Torr のとき の発光輝度と高周波電力との関係を示す。図 2 によれば $\mathrm{Hg}$ 蒸気圧が $2 \times 10^{-3}$ Torr のとき, $10 \sim 100 \mathrm{~W}$ までは，放電電 力の増加に伴って輝度は順調に增加傾向にあるが, $100 \sim 2$ $00 \mathrm{~W}$ では增加傾向は緩やかになっている輝度は $50 \mathrm{~cd} / \mathrm{m}^{2}$ ま で上昇した。 $\mathrm{Hg}$ 蒸気圧 $2 \times 10^{-4} \mathrm{Torr}$ では，ほほ同じ傾きで増加しており $25 \mathrm{~cd} / \mathrm{m}^{2}$ 程度まで上昇した。 図3では, $2 \times 10^{-3}$ Torr のとき $100 \mathrm{~W}$ まで放電電力の增加に伴い増加傾向を示すが, $100 \mathrm{~W}$ を越える

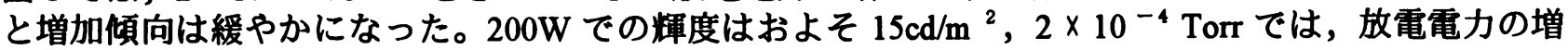
加に伴い輝度は順調な增加を示しおよそ $30 \mathrm{~cd} / \mathrm{m}^{2}$ まで上昇した。

\section{4.まとめ}

0.1Torr の結果では Ne-Hg の輝度の方か Ar-Hg より高かった。また Ar-Hg では $\mathrm{Hg}$ 蒸気圧の低い方 が輝度は高くなった。

\section{参考文献 （1）高周波放電を用いた無電柾光源の発光特性 平成 11 年度照明学会全国大会 No.32}

Luminance characteristics of phosphor light emission in a radio frequency electrodeless discharge plasma.

-Effect of $\mathrm{Hg}$ vapor pressure on luminance characteristics -

Hidenori Kashiwazaki, Yasunori Ohtsu, Hiroharu Fujita

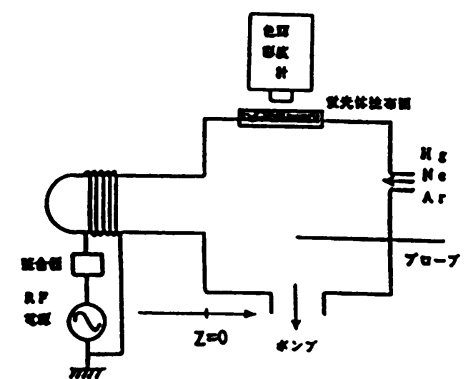

困 1 実験装置

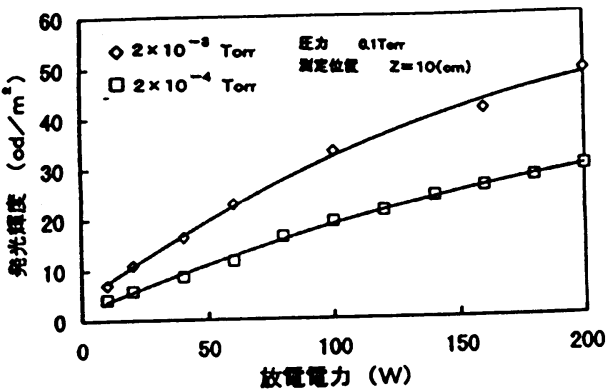

図2 放電電力を変えた時の発光輝度

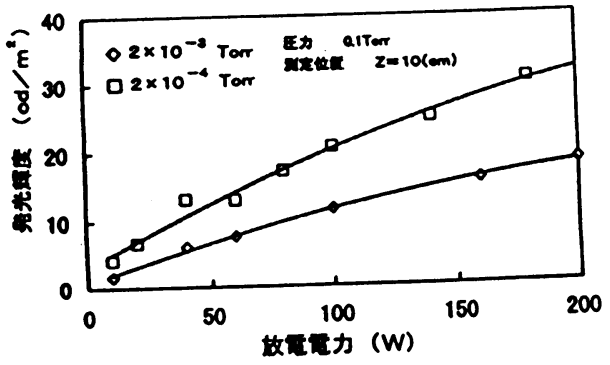

図 3 放電電力を変えた時の発光輝度 (Ar-Hg) 